\title{
Origin of the Hawaiian rainforest and its transition states in long-term primary succession
}

\author{
D. Mueller-Dombois ${ }^{1}$ and H. J. Boehmer ${ }^{2}$ \\ ${ }^{1}$ University of Hawaii at Manoa, Department of Botany, 3190 Maile Way, Honolulu, HI 96822, USA \\ ${ }^{2}$ Technical University of Munich, Department of Ecology and Ecosystem Management, Chair for Strategic Landscape \\ Planning and Management, Emil-Ramann-Strasse 6, 85350 Freising-Weihenstephan, Germany
}

Correspondence to: D. Mueller-Dombois (dieter@hawaii.edu)

Received: 31 December 2012 - Published in Biogeosciences Discuss.: 11 February 2013

Revised: 3 June 2013 - Accepted: 21 June 2013 - Published: 30 July 2013

\begin{abstract}
This paper addresses the question of transition states in the Hawaiian rainforest ecosystem with emphasis on their initial developments. Born among volcanoes in the north central Pacific about 4 million years ago, the Hawaiian rainforest became assembled from spores of algae, fungi, lichens, bryophytes, ferns and from seeds of about 275 flowering plants that over the millennia evolved into ca. 1000 endemic species. Outstanding among the forest builders were the tree ferns (Cibotium spp.) and the 'ōhi'a lehua trees (Metrosideros spp.), which still dominate the Hawaiian rainforest ecosystem today. The structure of this forest is simple. The canopy in closed mature rainforests is dominated by cohorts of Metrosideros polymorpha and the undergrowth by tree fern species of Cibotium. When a new lava flow cuts through this forest, kipuka are formed, i.e., islands of remnant vegetation. On the new volcanic substrate, the assemblage of plant life forms is similar to the assemblage during the evolution of this system. In open juvenile forests, a mat-forming fern, the uluhe fern (Dicranopteris linearis), becomes established. It inhibits further regeneration of the dominant 'ōhi'a tree, thereby reinforcing the cohort structure of the canopy guild. In the later part of its life cycle, the canopy guild breaks down often in synchrony. The trigger is hypothesized to be a climatic perturbation. After the disturbance, the forest becomes reestablished in about 30-40 yr. As the volcanic surfaces age, they go from a mesotrophic to a eutrophic phase, reaching a biophilic nutrient climax by about 1-25 K yr. Thereafter, a regressive oligotrophic phase follows; the soils become exhausted of nutrients. The shield volcanoes break down. Marginally, forest habitats change into bogs and stream ecosystems. The broader 'ōhi'a rainforest
\end{abstract}

redeveloping in the more dissected landscapes of the older islands loses stature, often forming large gaps that are invaded by the aluminum tolerant uluhe fern. The 'ōhi' a trees still thrive on soils rejuvenated from landslides and from Asian dust on the oldest ( 5 million years old) island Kaua'i but their stature and living biomass is greatly diminished.

\section{Introduction: origin and evolution of Hawaii's rainforest}

The Hawaiian rainforest was born among volcanoes in the north central Pacific in complete isolation. Its origin is ancient, probably pre-Pleistocene. The latest information gives the date of colonization of its dominant tree taxon Metrosideros ('ōhi'a lehua) as 3.9 (to 6.3) Myr (Percy et al., 2008). This date range, obtained from phylogenetic methods, puts its island origin into the Pliocene, coinciding with the emergence of the oldest high island Kaua'i. The arrival date of the second main structural component of the Hawaiian rainforest, the tree fern Cibotium (hapu'u), has not yet been established, but is believed to be of equally ancient origin (Ranker, personal communciation, 2012). Even today, the early community assemblage on new volcanic surfaces follows the evolution of plant life from algae and fungi via lichens, mosses, and ferns (Smathers and Mueller-Dombois, 2007). However, seed plants now arrive early, commonly after $4 \mathrm{yr}$, with the endemic Metrosideros polymorpha tree among the first.

The Hawaiian flora of seed-bearing plants consists of about 275 successfully established indigenous populations 
(Fosberg, 1948; Wagner et al., 1999). They arrived by longdistance transfer either by wind in the jet streams (small seeds only, such as those of Metrosideros, as did the fern spores and lower plant forms) or attached to the feet, feathers or in the guts of storm tossed birds (Carlquist, 1980). A minor number of plant propagules arrived within ocean currents. Most of the latter form Hawaii's native coastal vegetation, which is rather impoverished compared to those of the islands in Micronesia and Melanesia (Mueller-Dombois and Fosberg, 1998). This process of natural invasion took many millennia. In that period new species evolved as endemics from only about $10 \%$ of the original colonizers. Together they now form a native Hawaiian flora of about 1000 species (Wagner et al., 1999).

\section{Early primary succession}

Three distinct stages in early rainforest succession can be recognized.

\subsection{Stereocaulon lichen stage}

When a lava flow cuts through a Hawaiian rainforest, patches of rainforest often survive as so-called kipuka, i.e., islands of remnant vegetation (Fig. 1). These vegetation islands and nearby intact vegetation provide most of the propagules for plant invasion on the new volcanic surfaces (e.g., Drake, 1992; Drake and Mueller-Dombois, 1993; Kitayama et al., 1995). Typically, such invasion starts with blue-green algae, such as Anacystis montana, Scytonema myochrous, Stigonema panniforme, among others. Early mosses include species of Campylopus and Rhacomitrium lanuginosum. These settle in lava fissures together with low-growing fern species of Nephrolepis and Pityrogramma. A lichen, Stereocaulon vulcani, becomes obvious in four years, often growing as continuous cover on lava rock surfaces. Together with the invasion of this white-grey dendroid lichen, invasion of seed plants are noted. They include typical native pioneer shrubs such as Dubautia scabra, Vaccinium reticulatum, and species of endemic Rumex. Simultaneously, tree seedlings of Metrosideros polymorpha appear in the lava cracks, soon developing into saplings (Fig. 2). Early successional shrubs, such as the native Coprosma ernodeoides, Leptecophylla tameiameiae, and Dodonaea viscosa soon begin to supplement the first group.

In the lichen stage, rock fissures become filled with mineral dust and organic matter and the Stereocaulon itself is known to work on the breakdown of the rock surfaces (Jackson, 1969) by producing carbonic acid and thus releasing iron chelates, an essential plant nutrient. Potassium is another soil nutrient dissolved early from glass-coated basalt fragments. Limited amounts of atmospheric nitrogen become available from fixation by blue-green algae.

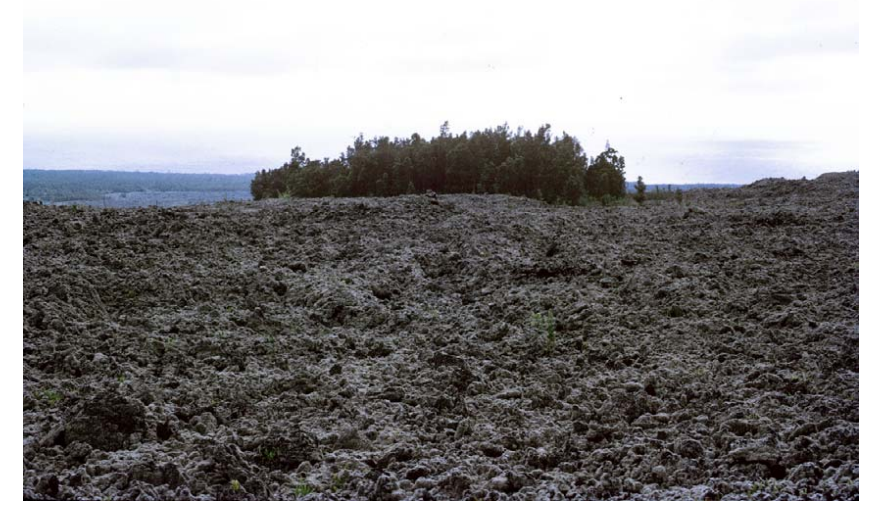

Fig. 1. The 1955 Kamā'ili 'a'ā flow with kipuka in background (photo by D. Mueller-Dombois, 1971).

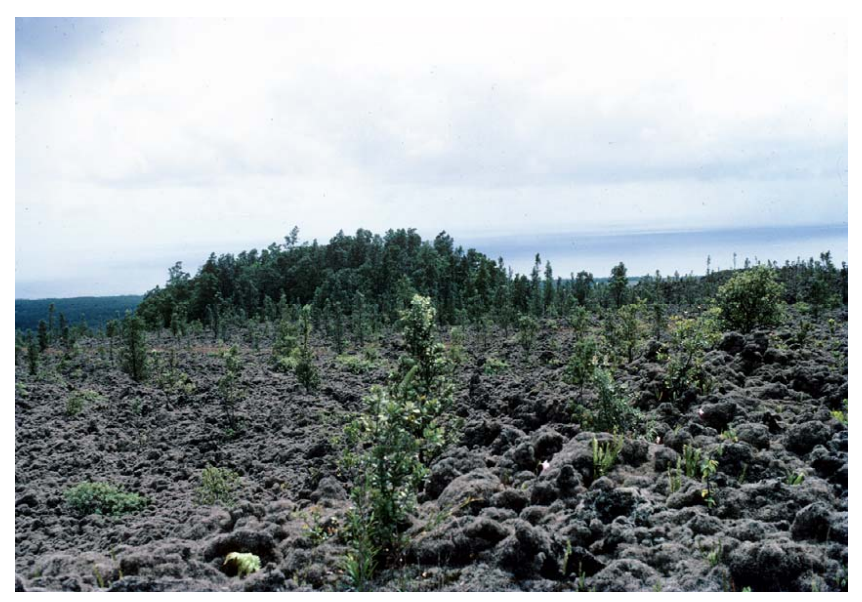

Fig. 2. The same Kamā'ili 'a'à flow fourteen years later with cohort of Metrosideros saplings (photo by D. Mueller-Dombois, 1985).

\subsection{Dicranopteris fern stage}

After about 50-100 yr, the new Metrosideros seedlings have grown into a juvenile tree stand. Typically at this advanced stage, the native uluhe fern (Dicranopteris linearis) has moved onto the new volcanic substrate beneath the trees (Fig. 3). Juvenile Metrosideros trees have rather short branches along their entire stems, and the trees thus form open stands, which allows for much direct sunlight to penetrate to the ground. This light environment is ideal for the heliophytic fern Dicranopteris linearis, a stoloniferous mat-former, which covers the open bedrock surface, thereby preventing further Metrosideros seedlings to develop into saplings. Metrosideros seedlings are relatively shade tolerant but they only grow into the sapling stage in well lighted situations (Burton and Mueller-Dombois, 1984). Thus there is a switch from shade-tolerance to shade-intolerance in Metrosideros seedlings (height range from 10-30 cm). Seedlings 


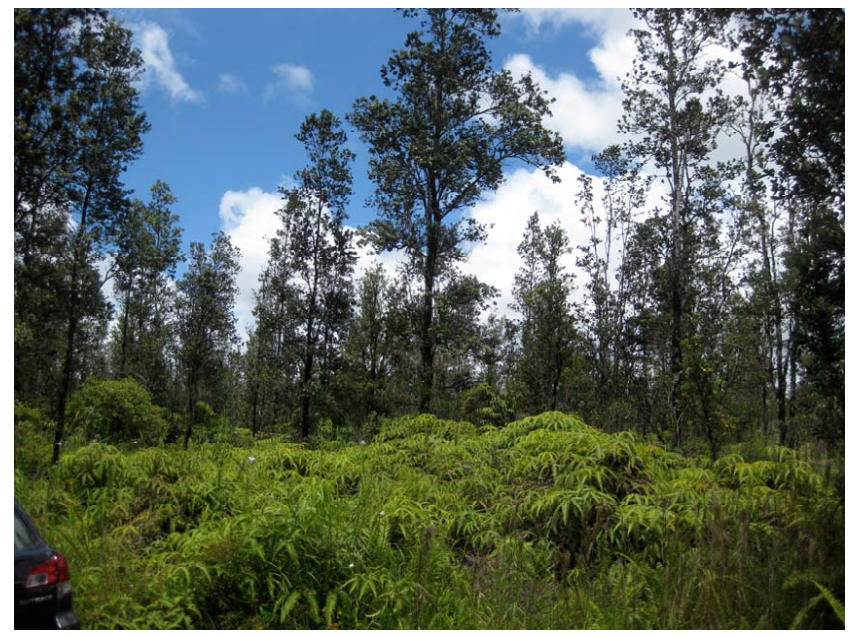

Fig. 3. Juvenile Metrosideros forest with uluhe fern (Dicranopteris linearis), a heliophytic mat-former. The young trees, growing typically in open formation, have short branches along their stems, and the undergrowth receives much direct sunlight (photo by D. Mueller-Dombois, 2011).

require direct sunlight to grow into trees. The change in undergrowth through invasion of the mat-forming fern is in part responsible for the cohort structure of Metrosideros canopy forests. Raw humus begins to accumulate under the fern cover, signaling the early stage of histosol development (Burton and Mueller-Dombois, 1984).

\subsection{Cibotium tree-fern stage}

When the juvenile trees reach maturity, they shed the short stem branches and their crowns connect and overlap, forming a closed canopy. Dicranopteris linearis retreats with the increased shade and the Cibotium tree ferns become prominent in the undergrowth (Fig. 4). The latter are shade tolerant. The organic overlay gains in depth largely due to wilted tree fern fronds being added. Raw humus with fungal and insect life is formed; the substrate can now be classified as typical "histosol".

\section{Cohort forest structure}

Figures 4-6 illustrate the simple structure of the Hawaiian rainforest, which results from cohorts (generation stands) that develop after major disturbances. Its evolution in isolation provides for only a limited tree flora with equally limited pioneer functions of the endemic key species Metrosideros polymorpha. It colonizes new volcanic substrates and thereafter maintains its dominance as the principal canopy species by auto-succession over numerous generations in the aggrading phase of primary succession.

In some less wet old-growth rainforests, the endemic Acacia koa is often associated as being a second tall-growing

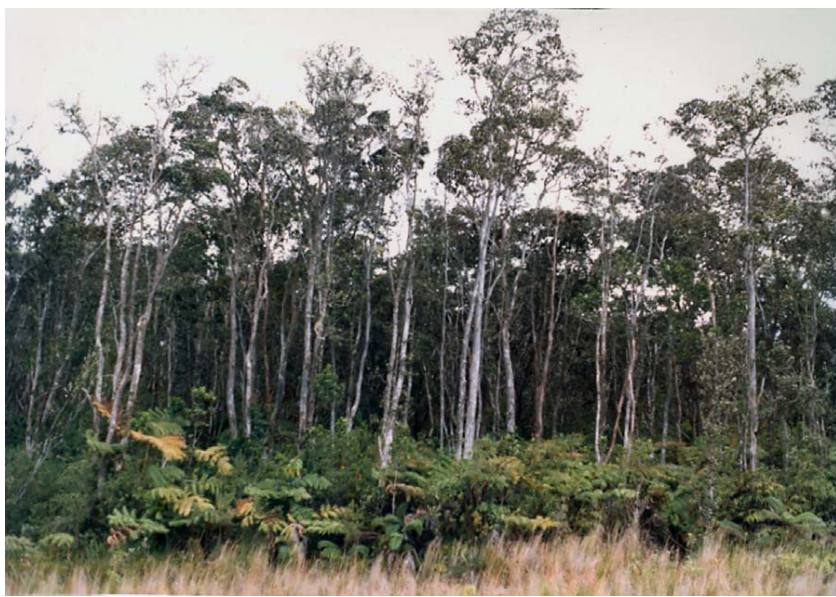

Fig. 4. Mature Metrosideros forest with Cibotium tree fern undergrowth in lowland near Kalapana, Hawaii Island. Broomsedge grass (Andropogon virginicus) in foreground (photo by D. MuellerDombois, 1984).

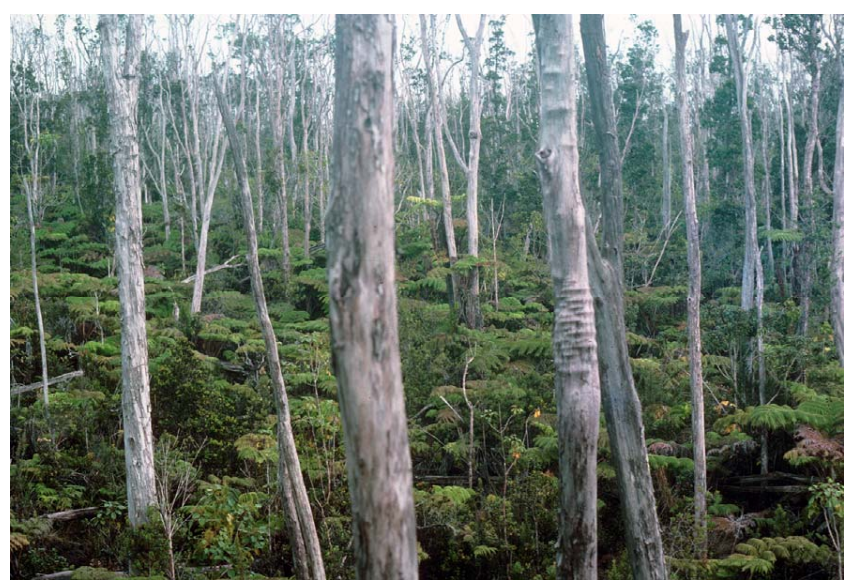

Fig. 5. Wetland dieback forest at a Tree Planting Road plot (photo by James D. Jacobi, 1976).

canopy tree. It is also a pioneer tree, but it prefers soil substrates (regosols) rather than lava rock habitats. The Hawaiian rainforest lacks late successional canopy tree species (Mueller-Dombois et al., 2013). Other native tree species, such as Ilex anomala, Myrsine lessertiana, Cheirodendron trigynum, Coprosma rhynchocarpa (to name a few), form sub-canopy trees. Dominant in the undergrowth is a distinct layer of hapu'u tree ferns, Cibotium spp. In open forest the undergrowth is often dominated by the mat-forming fern $\mathrm{Di}$ cranopteris linearis.

\section{Canopy dieback}

Canopy dieback (Figs. 5 and 6) is a special form of treegroup dieback. It starts with the loss of crown foliage out of season, and ends in tree mortality. It is thus distinguished 


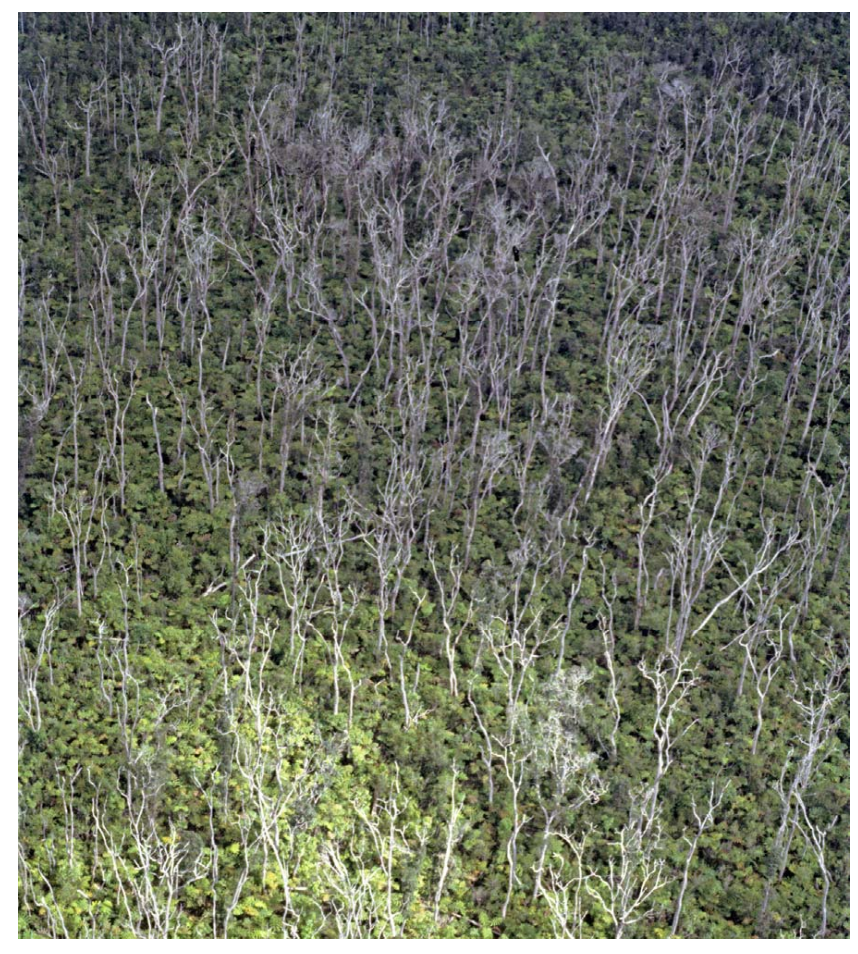

Fig. 6. View from helicopter (of same dieback area as shown on Fig. 5) clearly shows the cohort stand structure of the canopy tree 'ôhi'a lehua (Metrosideros polymorpha). Note the healthy undergrowth of mostly hapu'u (Cibotium sp.) tree ferns (photo by James D. Jacobi, 1976).

from the loss of foliage of deciduous trees, who seasonally lose and replace their crown foliage. Canopy dieback can result from several causes. Commonly suspected reasons are disease, air pollution, or climate change (Auclair, 1993; Boehmer, 2011a).

When canopy dieback spread rapidly in the native Hawaiian rainforest from the mid-1960s through the mid-1980s (Jacobi et al., 1988; Fig. 7), a new "killer disease" was suspected. A decade of thorough disease research ended with the findings that two biotic agents were considered marginally involved (the indigenous root pathogen Phytophthora cinnamomi and the endemic 'ōhi'a bark beetle Plagithmysus bilineatus), but that the trees were dying from an unknown cause (Papp et al., 1979). A subsequent review declared the canopy dieback to be a typical decline disease (Hodges et al., 1986). A decline disease is seen as a multi-factorial "death spiral" according to Manion (1991), whereby the causes of death remain unclear.

An alternative to the decline disease theory is the cohort senescence theory (Mueller-Dombois, 1992a). It explains canopy dieback in the native Hawaiian rainforest as a rapid state of transition involving auto-succession. When canopy guilds or cohorts break down in the later part of their life cycle, that process can be attributed to aging (loss of energy or vitality). Aging is not a disease; it is the fundamental real-

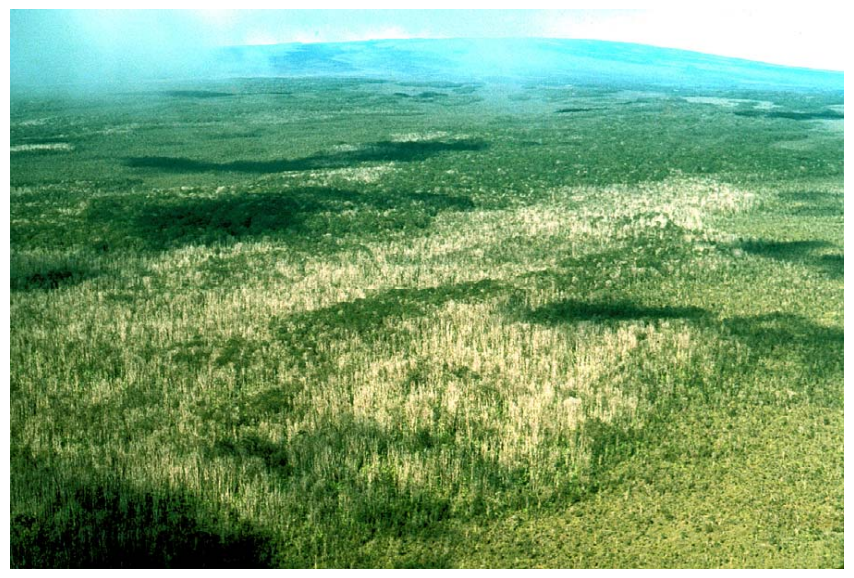

Fig. 7. Aerial view of cohort mosaic and landscape-level dieback on east slope of Mauna Loa (photo by James D. Jacobi, January 1983).

ity of life in trees as well as in all other sexually reproduced organisms whose life cycle is genetically programmed.

\section{Cohort senescence}

We can attribute cohort senescence in the Hawaiian rainforest to four basic factors:

- $\mathrm{S}=$ simple structure, tree individuals forming a generation, like a plantation stand

- $\mathrm{E}=$ edaphic constraint, imbalanced soil nutrients, unfavorable soil-water relations

- $\mathrm{P}=$ perturbation, a recurring minor disturbance event, a trigger factor

$-\mathrm{B}=$ biotic agents

To explain the Hawaiian rainforest dieback, these four factors were arranged in a chain reaction involving three phases:

- Predisposing factors: S, E, P

- Precipitating or trigger factors: $\mathrm{P}$

- Modifying factors: B (when present, may accelerate canopy dieback)

This was presented as a unifying theory for forest canopy dieback at the 1987 International Botanical Congress in Berlin (Mueller-Dombois, 1988a, b).

The $\mathrm{S}$ and $\mathrm{B}$ factors have already been clarified in the preceding discussion. The $\mathrm{P}$ factor will be clarified next. The $\mathrm{E}$ factor will become apparent below in the subtopic, long-term succession. 


\section{Climatic perturbations}

The predisposition to canopy dieback in the Hawaiian rainforest was found primarily in (1) the origin of its biota, (2) the evolution-in-isolation of its species and ecosystems, (3) the simplified structure in the form of generation stands (cohorts), and (4) the canopy's demographic history.

The precipitating or triggering factor for canopy dieback remained unsolved. Seismic tremors were once suspected as dieback triggers, but the patterns did not correlate at all (Mueller-Dombois, 1992b). Air pollution from volcanic fumes was not considered to be responsible either, nor was global warming in terms of climate change (MuellerDombois, 1992b). Climatic perturbations were difficult to ascertain as trigger factors in spite of several climate analyses (e.g., Doty, 1982; Evenson, 1983; Hodges et al., 1986). However, a more detailed climatic analysis done on a month-tomonth basis yielded a clue (Fig. 8).

Such an analysis was done from continuous monthly rainfall data from 1900-1984 available from the Hilo airport station (Mueller-Dombois, 1986). This station is located centrally below the two adjacent mountains, Mauna Kea and Mauna Loa. The canopy dieback occurred upslope from Hilo in the wet windward rainforest territory. The progression of canopy dieback became evident from the mid-1950s through the mid-1980s.

First, the long-term mean annual rainfall was divided by 12 to reduce it to a monthly basis. Then the mean rainfall of each individual year was divided by 12 and projected over the long-term mean. This resulted in 84 individual rainfall years that oscillated to either side of the long-term mean projected as a straight line. It showed that the first $50 \mathrm{yr}$ tended to be wetter than the following $34 \mathrm{yr}$.

In the rainforest, canopy wilting was observed when the monthly rainfall was less than $50 \mathrm{~mm}$ ( $2 \mathrm{in}$.). This value was used as a drought index. Impounding of surface water on poor to moderately drained soils was detected when the monthly rainfall exceeded $750 \mathrm{~mm}$ (30 in.). This value was used as flood index. The 1008 monthly values were analyzed in relation to these indices.

During the first $50 \mathrm{yr}$, from 1900 to 1950 , there were 9 drought months and 14 flood months. In the next $34 \mathrm{yr}$ there were 7 drought months and 8 flood months. This shows that the frequency of extreme months did not increase from the first 50 to the following $34 \mathrm{yr}$ when the canopy dieback took place.

A second analysis using more extreme threshold values gave insight into climate change. Intensified drought was considered when the monthly rainfall was less than $10 \mathrm{~mm}$ (0.4 in.) or when two months in a row had less than the $50 \mathrm{~mm}$ rainfall. Intensified flooding was considered when rainfall exceeded $1000 \mathrm{~mm}$ (40 in.) or two months in a row had more than $750 \mathrm{~mm}$ rainfall. These intensified climatic perturbations are indicated by asterisks in Fig. 8 .

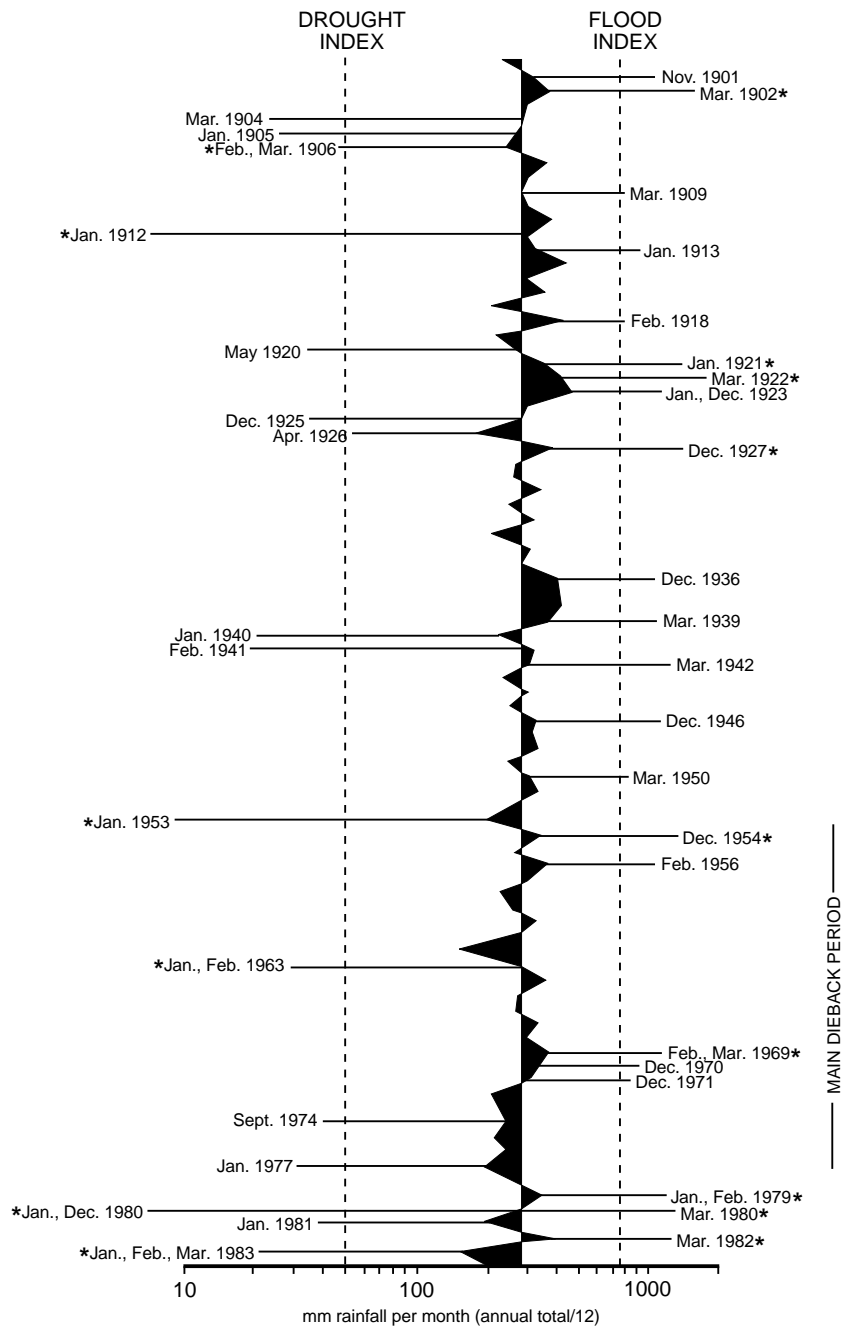

Fig. 8. Extreme rainfall months at Hilo airport from 1900 to 1984. Months with $<50 \mathrm{~mm}$ ( 2 in.) rain are shown left of drought index and those with $>750 \mathrm{~mm}$ ( $30 \mathrm{in}$.) at right of flood index. Months marked with an asterisk $\left(^{*}\right)$ indicate intense drought or flood events (reproduced with permission from Annual Review of Ecology \& Systematics, 17, 231, 1986).

During the first $50 \mathrm{yr}$ this second analysis showed $2 / 9=22 \%$ intensified drought events and for the following $34 \mathrm{yr} 4 / 7=57 \%$. On the wet side, the first $50 \mathrm{yr}$ had $4 / 14=29 \%$ intensified flood events. The following $34 \mathrm{yr}$ had $5 / 8=63 \%$ intensified flood events. This clarifies that the intensities of climatic perturbations increased during the dieback period. It may also explain the synchrony of so many rainforest stands collapsing in the form of canopy dieback during those three decades.

\section{Auto-succession}

The decline disease interpretation for the Hawaiian rainforest (Hodges et al., 1986) suggested its demise. The 


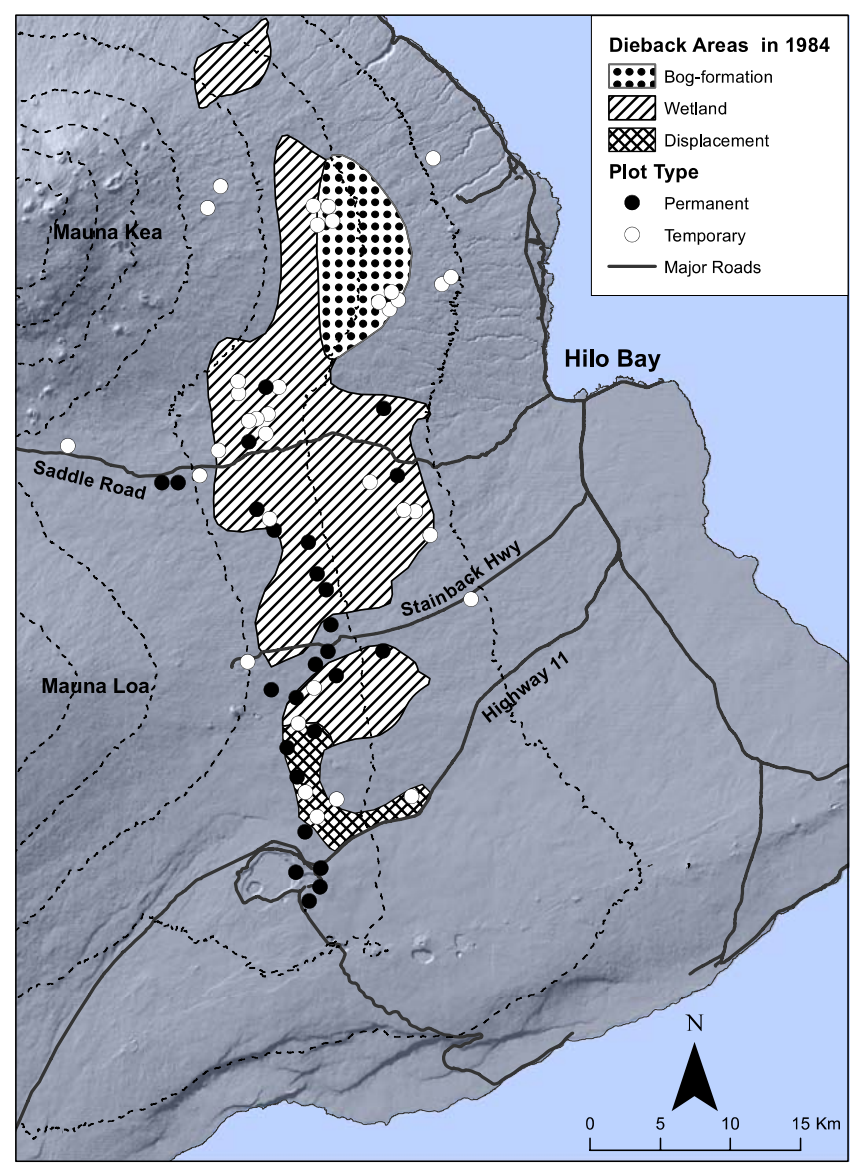

Fig. 9. The study area with plot locations. Black circles represent permanent plots (26/62). Three dieback types are shown. Dryland dieback refers to plots outside the mapped area, from the Saddle Road south into Hawaii Volcanoes National Park. Gap-formation dieback refers to plots on Mauna Kea in the wetland and bogformation territory (map after Jacobi et al., 1983).

cohort senescence interpretation (Mueller-Dombois, 1986) suggested a generation turnover by auto-succession. Autosuccession means self-succession, sometimes also called direct succession, which implies replacement with the same species after turnover or canopy dieback (Boehmer and Richter, 1997).

In 1976 we established 26 permanent plots, 13 in dieback and 13 in nearby non-dieback stands, and 36 additional temporary plots (Fig. 9); the permanent plots were remonitored approximately every $5 \mathrm{yr}$. In each of our 62 plots we measured tree diameters at breast height (DBH) of Metrosideros trees, including height measurements for seedlings and saplings. Subsequently, these measurements were synthesized into two diagrams to typify the size structure in nondieback and dieback stands (Fig. 10).

Note that mature non-dieback stands (type A) show a "sapling gap", implying that there are hardly any Metrosideros individuals beneath the closed tree canopies except
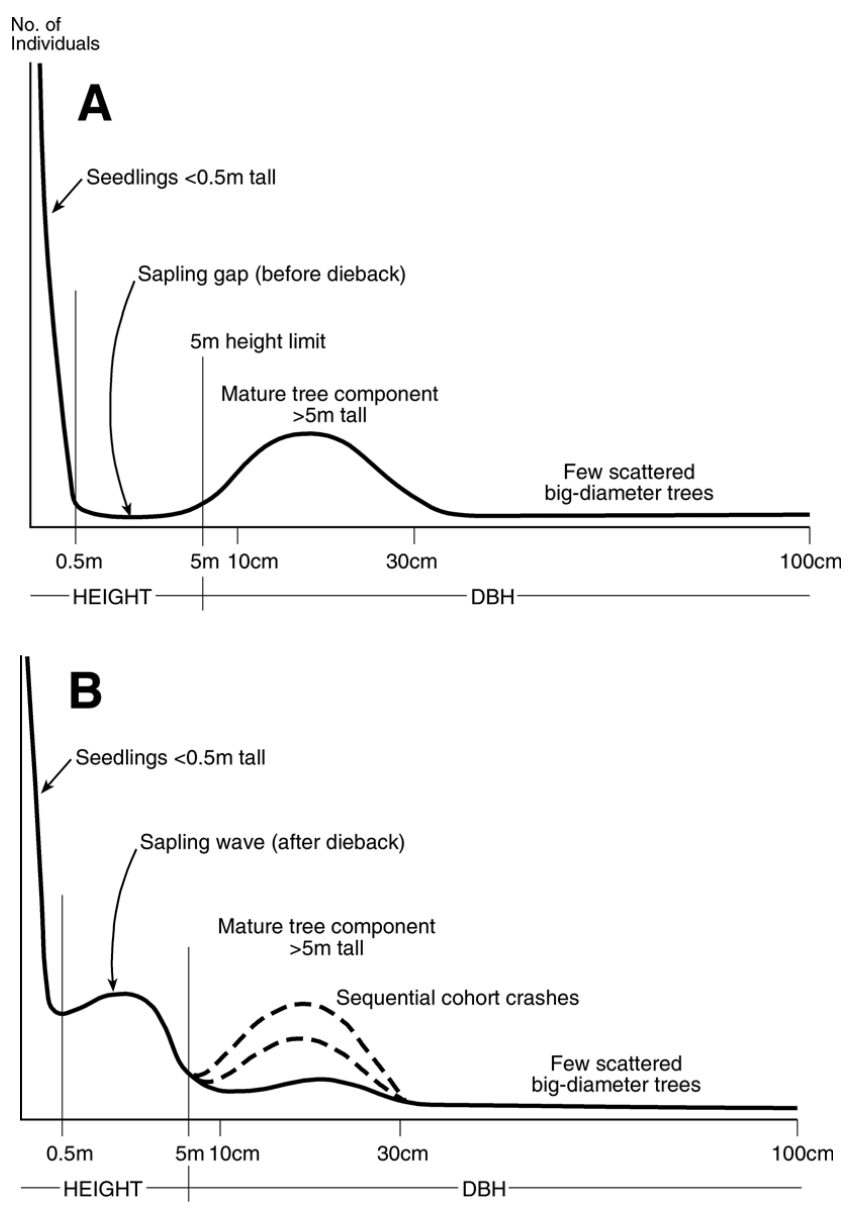

Fig. 10. Size frequency graphs of two Metrosideros cohort stands: type (A) in non-dieback condition; type (B) in dieback condition. Reproduced with permission from BioScience, 37, 580.

for a high number of seedlings. The canopy stand displays its cohort nature by the bell-shaped curve. In the broader surroundings of most sample stands we occasionally found some big-diameter trees that seemed to be survivors of former dieback events.

Type B depicts the forest in dieback condition. We observed during our field study period through repeated plot visits that certain dieback stands seemed to be affected by subsequent crashes, perhaps relating to a succession of climatic perturbations as dieback triggers. The most important outcome of canopy dieback is shown in the "sapling wave" that became recruited from existing shade-born seedlings as well as new light-born ones.

Initially, Metrosideros seedlings became more abundant right after canopy dieback (Jacobi et al., 1983). This was also experimentally shown after defronding tree fern stands that had lost Metrosideros overstory trees to dieback (Burton and Mueller-Dombois, 1984). Upon opening of the tree fern subcanopy, some shade-born seedlings died while others grew into saplings together with new light-born individuals. 


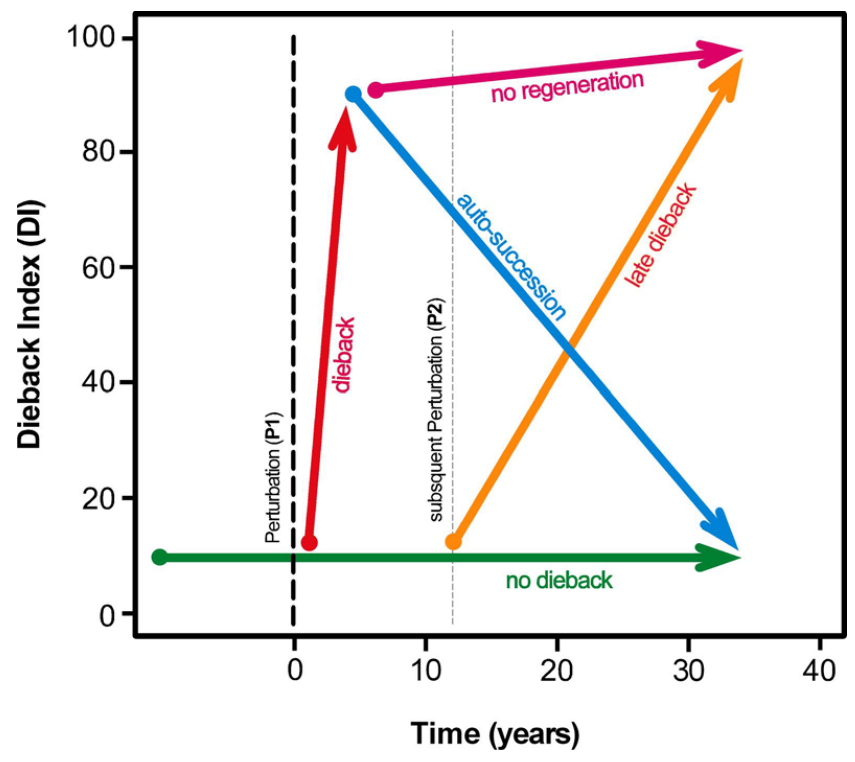

Fig. 11. Change of dieback index DI (proportion of dead or dying Metrosideros canopy trees per forest stand/cohort) over time, based on the results of $>30 \mathrm{yr}$ of permanent plot assessment in Hawaii's montane rainforest (Boehmer et al., 2013). Bold dashed line: major climatic perturbation (dieback trigger). Green arrow: stands not affected by dieback; red arrow: stands (old cohorts) affected by dieback; blue arrow: stands regenerating after dieback (auto-succession); pink arrow: stands not regenerating due to 'ōhi'a life cycle disruptors; orange arrow: cohorts affected by a subsequent perturbation (thin dashed line).

A major climatic perturbation (P1) triggers canopy dieback of senescent Metrosideros cohorts (red arrow) while younger cohorts remain unaffected (green arrow). A young cohort of Metrosideros trees replaces the declined canopy trees within ca. 30-40 yr (autosuccession; blue arrow), thereby lowering the proportion of dead canopy trees to the level of "no dieback" stands. This is not possible where alien 'ōhi' a life cycle disruptors inhibit natural regeneration (no regeneration; pink arrow); in such stands the DI remains high, eventually reaching $100 \%$. Over the years, subsequent perturbations (P2) can cause subsequent cohort crashes (late dieback; orange arrow).

Seedlings became less numerous in dieback plots as they developed into a sapling wave. This wave moved into the tree layer after ca. three decades (Fig. 11). The last reassessment was done in 2003 (Boehmer, 2005; Boehmer et al., 2013). By that time most of the dieback plots had fully recovered. In non-dieback stands, seedlings did not develop into saplings. They remained small and turned over periodically as new seedling crops.

\section{Long-term succession}

The native rainforest on the island of Hawaii forms a broad belt extending from south to north on the windward slopes from Kīlauea via Mauna Loa to Mauna Kea over a distance

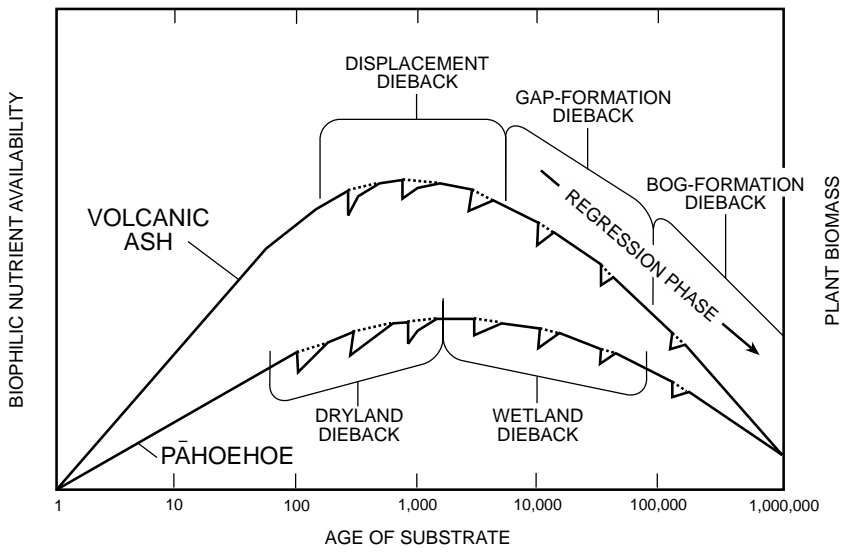

Fig. 12. A conceptual model of long-term primary succession of the two prevailing volcanic substrates in Hawaii with the five dieback types superimposed. Reproduced with permission from Annual Review of Ecology \& Systematics, 1986, 234.

of about $70 \mathrm{~km}$. In the lowland it starts above developed land at approximately $500 \mathrm{~m}$ and terminates in the upland area at $1500 \mathrm{~m}$ elevation under the inversion zone, an upland stretch of about $15 \mathrm{~km}$ (Jacobi et al., 1983). From south to north the mean annual rainfall increases from $2500 \mathrm{~mm}$ to $7500 \mathrm{~mm}$ (Juvik and Juvik, 1998), and the age of the substrate changes from young to old. It represents a chronosequence of aging landscapes.

We can consider the entire native forest belt from south to north as one rainforest ecosystem. This allows the spatial changes in the aging sequence to be viewed as extension of long-term primary succession. This concept was first projected in the form of a diagram (Fig. 12; Mueller-Dombois, 1986).

We recognized five dieback types. They are here named and shown along two curves representing the most important substrate types, volcanic ash and pāhoehoe lava. Ash here stands for all pyroclastic substrates, including 'a' à lava and cinder. The curves indicate soil and vegetation development over a logarithmic timescale. Soil development relates to biophilic nutrient availability and vegetation development to living plant biomass. Both increase relatively fast and decrease relatively slowly. The dieback types are defined by substrate.

Dryland dieback was found to occur on well-drained sites, not only on pāhoehoe, but also on volcanic ash, cinder, and 'a'ā lava (although not shown as such on the diagram).

Wetland dieback (Figs. 5, 6) was found mostly on poorly drained, thus older, pāhoehoe lava with an accumulation of organic matter concentrated on the lava fissures (histosols). Wetland dieback was the most common and widely spread type of dieback, its boundaries often coinciding with the areal extent of the underlying flow (Akashi and Mueller-Dombois, 1995). 


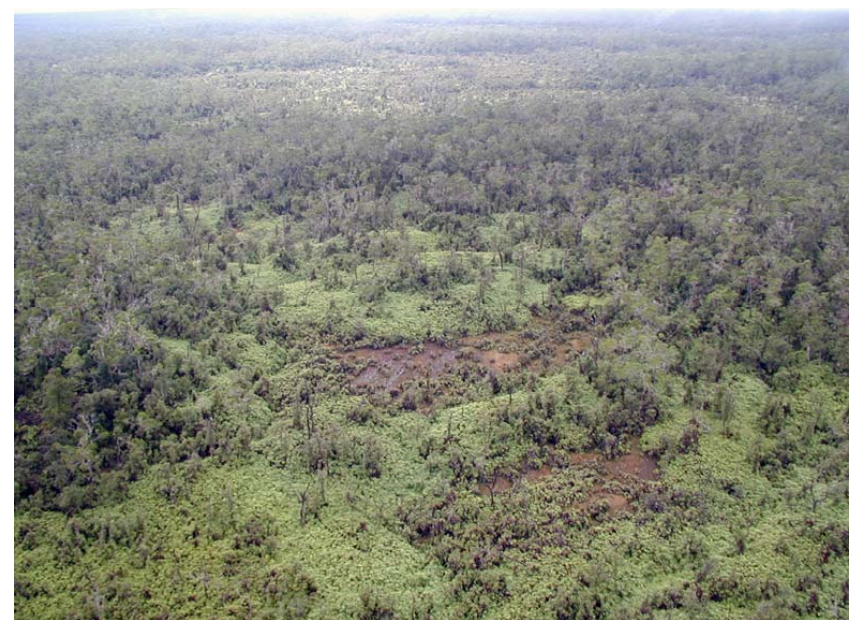

Fig. 13a. Aerial view of cohort mosaic on east slope of Mauna Kea with two bogs and gap-formation dieback with Dicranopteris fern patches underneath dying Metrosideros tree groups (photo by Rick Warshauer, April 2005).

Displacement dieback was typically associated with the eutrophic peak in soil development. Displacement implied that auto-succession was not functioning due to competition by tree ferns. Nowadays alien tree species account for displacers of the native 'ōhi'a tree after dieback (Minden et al., 2010a, b). In contrast, wetland and dryland diebacks were described as replacement types of dieback, meaning that the turnover in the form of auto-succession was applicable. This was later borne out by our permanent plot research referred to above.

Gap-formation and bog-formation dieback (Fig. 13a, b, c) occur in the regression phase of primary succession. That means they relate to the older nutrient impoverished (oligotrophic) sites on Mauna Kea. Such diebacks were also found on the older islands, for example the historic bog-formation dieback on the lower windward slope of Haleakalā mountain on Maui Island (Lyon, 1919; Mueller-Dombois, 2006).

Note that the secondary successions, which always begin after canopy dieback, are indicated by checkmarks on both curves. On the declining, longer-time segments of each curve, i.e., the regression phase, living biomass also declines after each dieback (Kitayama and Mueller-Dombois, 1995). This is also indicated in the conceptual model (Fig. 12).

\section{Soil and geomorphic aging}

Bog-formation dieback is a distinct indicator of a transition phase in geomorphic aging. On windward Mauna Kea and Haleakalā it is associated with stream formation and breakdown of the volcanic shield. Here Metrosideros displays complete die-off where streams are formed. But new Metrosideros trees come up on stream banks when new streams have cut deeper into the substrate (Mueller-Dombois, 2006).

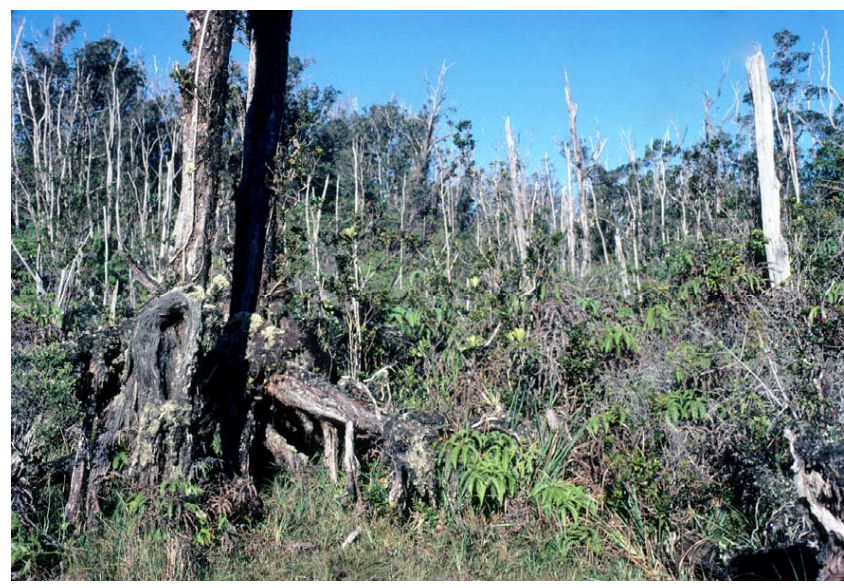

Fig. 13b. Gap-formation dieback north of Wailuku stream at $1200 \mathrm{~m}$ (4000 ft.) elevation.

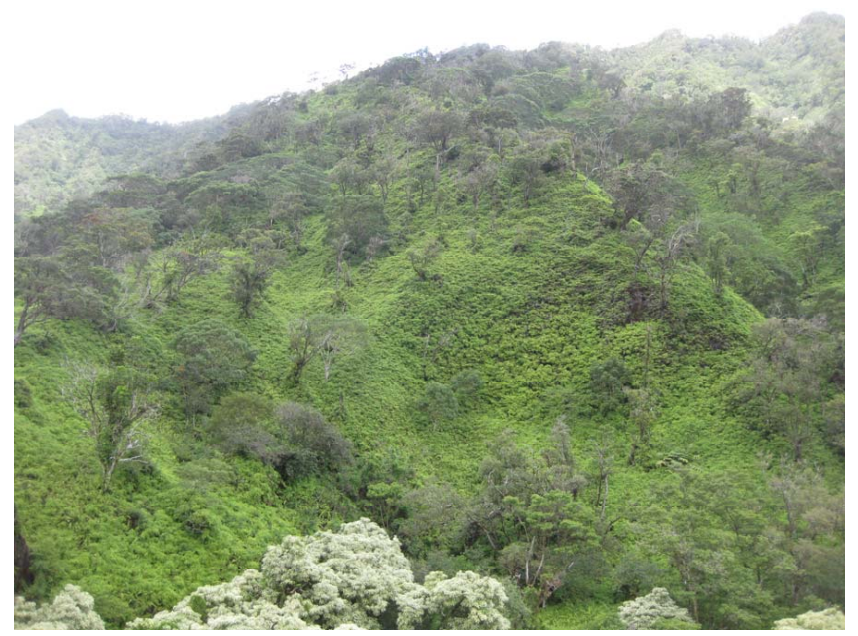

Fig. 13c. Metrosideros gap-formation dieback in the 2.6 million year old Ko'olau mountain range on O'ahu island. Here the outcome indicates development of fern (Dicranopteris linearis) savannas. The light-green metallic foliage reaching from below belongs to Aleurites moluccana (kukui tree, a Polynesian introduction, which now occupies many stream gullies on O'ahu island).

Soil research revealed nutrient stress in the form of low nitrogen supply early in primary succession, while immobilization of phosphorus became the most limiting factor in late primary succession (Vitousek, 2004). An investigation of the long-age soil succession gradient (Fig. 14) shows a nutrient accumulation and nutrient depletion curve similar to the progressive and regressive forest succession curves in Fig. 11.

A geomorphic analysis by Wirthmann and Hueser (1987) characterizes the next step in landscape change as progressing from a younger Hawaiian island to an older one (Fig. 15). Certainly, geomorphic aging has brought about new forest habitats, which originally were occupied by Metrosideros 


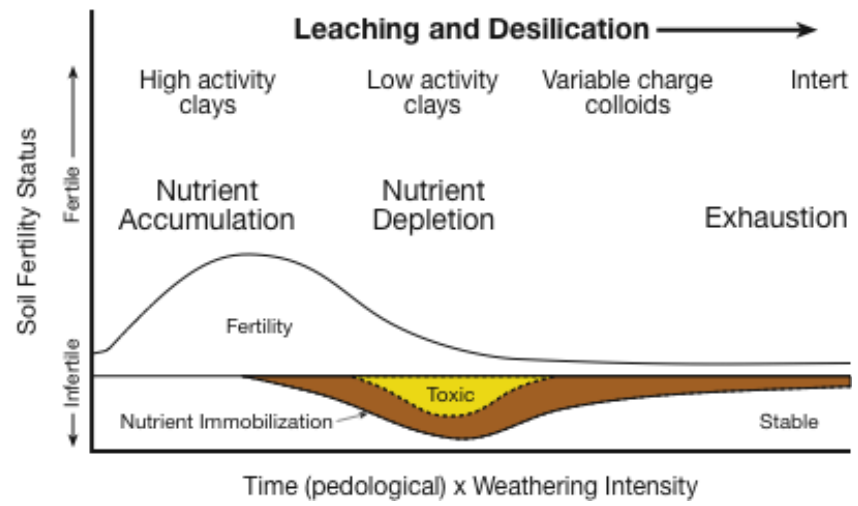

Fig. 14. Tropical soil formation and degradation, an independently designed conceptual model that matches the long-term primary successional model shown in Fig. 12 above. From Fox et al. (1991) with permission from Allertonia, a journal of the National Tropical Botanic Garden on Kaua'i Island.

polymorpha with many generations (about 2-3 regeneration cycles per $1000 \mathrm{yr}$ ) on the wetter sites and by Acacia koa on the less wet or mesic sites. However, because of the introduction of so many tall growing late-successional species (or Kspecies), these native pioneer species have become displaced in particular from the lowland on the older Hawaiian islands.

\section{Conclusions: state transitions in the Hawaiian rainforest ecosystem}

The process of early primary succession has been described by one lichen and two fern stages that succeed one another while the same tree stand develops from juvenile to mature Metrosideros polymorpha dominated rainforest in about 200 to $400 \mathrm{yr}$. As a colonizer tree, this Hawaiian key species becomes established in cohorts, forming stands similar to planted forests. It maintains its pioneer function from generation to generation along the island age sequence, although large cohorts become smaller as the volcanic landscapes age.

Stand-level collapse from the mid-1960s to mid-1980s came as a surprise to most forest scientists in Hawaii. It was initially thought to be an introduced killer disease. After ten years of intensive disease and insect pest research it was dubbed "decline disease" (Hodges et al., 1986).

Ecological research revealed the rainforest ecosystem as a cohort mosaic (Figs. 7, 13a). Individual cohort stands behave similar to tree individuals. As cohort stands, they perform their growth cycles in synchrony. Predisposition to dieback includes the synchronized origin, various site specific habitat constraints during stand demography, and finally cohort senescence (a reduced stage of vitality). At that life stage only a trigger is needed to initiate stand-level collapse.

We defined five types of dieback along the long-term successional substrate age gradient. The first two, wetland dieback and dryland dieback, were recognized as "replace-

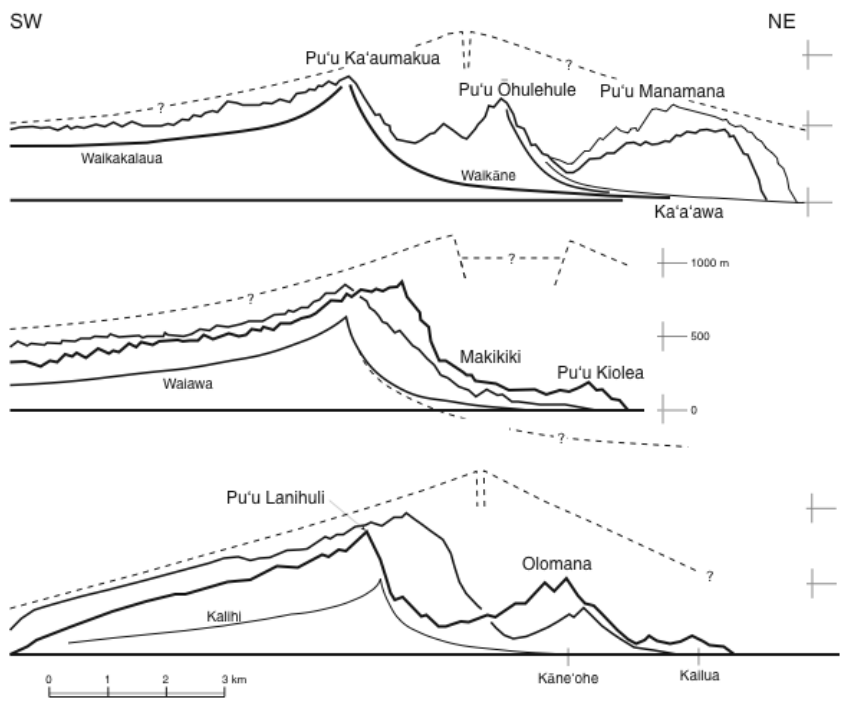

Fig. 15. This diagram (from Wirthmann and Hueser, 1987) demonstrates the outcome of breakdown of a Hawaiian shield volcano. The diagram shows three topographic profiles crossing from SW to NE through the windward Ko'olau mountain range of O'ahu Island. The slope reduction to this level of contemporary topography took 2.6 million years on the rain- and trade wind exposed west side of the island. In addition to regular stream erosion there were sudden break-offs of whole slope segments that rolled into the ocean, where they now form small, offshore islands.

ment diebacks", meaning that the dieback species will form the replacement canopy (a process referred to as autosuccession, also "direct" secondary succession). Another form, recognized by us as "displacement dieback", implied that the dieback species will be displaced by another canopy species (in the literature generally referred to as "normal" secondary succession). Two more dieback types (gapformation and bog-formation) in the regression phase were recognized as "stand reduction diebacks". This means that the follow-up recovery with Metrosideros trees would be less than complete.

Finally, a major state transition of the initially large rainforest ecosystem to a diversity of smaller ecosystems was recognized with soil and geomorphic aging and the stand reduction types of dieback. Bog-formation dieback was clarified as initiating a real landscape change including stream formation (Mueller-Dombois, 2006). Gap-formation dieback was observed to have different outcomes. In some areas it changed into Dicranopteris fern savannas, in others to smaller and more diverse rainforest communities.

We conclude by enumerating the important state transitions in the Hawaiian rainforest ecosystem as follows: 


\section{Early development}

1. A new terrestrial substrate is formed from a volcanic eruption.

2. Lower plant life-forms arrive and develop early from airborne spores (year 1).

3. Arrival of the keystone tree species follows in the form of colonizing cohorts (year 4).

4. Tree individuals are widely spaced; a mat-forming fern spreads underneath $(\sim 50 \mathrm{yr})$.

5. The mat-former prevents further influx of the keystone colonizer tree ("sapling gap").

\section{Maturation}

1. Tree canopy closure subdues the mat-forming fern and favors tree-fern undergrowth.

2. With the tree ferns an assortment of arborescent shrubs appear (diversity increases).

3. Tree fern trunks serve as sites for establishment of a variety of epiphytes.

4. An epiphytic start facilitates most native sub-canopy trees to become established.

5. On favorable sites the mature cohort forest remains vigorous for at least $400 \mathrm{yr}$.

6. On marginal sites the vitality of cohort stands begins to decline $(\sim 200 \mathrm{yr}$.)

\section{Canopy collapse and auto-succession}

1. Loss of vitality due to growth under habitat stress (premature senescence).

2. Loss of vitality due to genetically programmed life cycle (senescence).

3. Canopy opens and auto-succession (self-replacement) begins.

4. A "sapling wave" takes over and replaces the collapsed canopy cohort $(\sim 30 \mathrm{yr})$

5. Canopy redevelopment is restricted to wetland and dryland dieback.

\section{Long-term ecosystem development}

1. At the eutrophic peak (1-25 K yr), auto-succession may not operate (competition).

2. In the regressive phase, stand-reduction dieback with next generation being stunted.

3. A hill-and-depression micro-topography develops on the older (Mauna Kea) landscape.

4. With this, cohort stands become smaller, adapting to the new micro-topography.

5. Gap-formation dieback starts in the depressions and expands over some hills.

6. Bog-formation dieback becomes restricted to watersoaked flats that drained slowly.

7. Slow drainage indicates the start of stream ecosystems, which develop downslope.

\section{Volcanic shield breakdown}

1. Submarine landslides and stream erosion are the most relevant causes.

2. The rainforest responds with gap-formation causing landslides and fern savannas.

3. In the absence of landslides, gap-formation can still result in auto-succession.

4. Ōhi'a lehua is remarkably resilient, still surviving in low-statured forest stands on the oldest high island of Kau'i and as dwarf tree in Kau'i's lowland bog (at Wahiawa).

\section{Epilogue}

The state transitions reported here relate to the naturally evolved dynamic strategies of the leading canopy tree in the indigenous Hawaiian rainforest ecosystem. We purposely left out the human influence, which is a major cause of habitat loss, particularly in the lowlands of all occupied islands, through urbanization, agricultural development, golf course construction, etc. Another even more important influence is the human initiated introduction of tree species that would not have arrived naturally in this isolated archipelago. The lowlands outside the developed areas are swamped with tree species having the floristic potential to overtop the native 'ohi'a trees. Thus they can be called "killer" trees (most of them late-successional or K-species) that took habitat away from the native 'ohi'a trees.

Tree species, pre-adapted to new volcanic surfaces, have been introduced and have become troublesome invasives. 
They include the nitrogen fixers, Albizia moluccana and $\mathrm{Ca}$ suarina equisetifolia, which became quickly established on Hawaii's new volcanic habitats in the lowlands. Morella faya (native to the Macaronesian islands) is an upland invader, where its aggressiveness is naturally restricted to the drier rainforest habitats.

The combination of pollination, dispersal strategies and the pre-adapted functional properties of these introduced tree species are likewise a threat for the survival of the native rainforest ecosystem in Hawaii. For example, Morella faya produces fruits that are distributed by birds, in particular the wide-ranging alien Japanese white-eye (Zosterops japonicus). In contrast, 'ōhi'a is dispersed by wind and has no nitrogen fixing capacity. Other troublesome invaders are the strawberry guava tree (Psidium cattleianum) that aggressively follows gap-formation dieback in the northern Ko'olau range (O'ahu). It forms thickets on rainforest soils scarified by feral pigs (Sus scrofa). Moreover, it is shade-tolerant and able to invade closed native rainforests without ground disturbance, but it does not overtop 'ōhi' a trees in height. There are also undergrowth invaders that render 'ôhi'a's autosuccession strategy as obsolete (Boehmer 2011b; Fig. 11). There will be no replacement with sapling 'ōhi'a if these undergrowth invaders are not removed through conservation management.

Another serious threat is invasion of new pest organisms. For example, a rust fungus, Puccinia psidii, has recently become established in Hawaii. It was discovered on 'ōhi' a lehua foliage in a nursery, but has caused little harm to this species so far. However, it has killed the introduced rose apple tree (Syzygium jambos) over wide areas (Loope and Uchida, 2011). Syzygium is a member of the myrtle family, as is the native Metrosideros and also Psidium cattleianum. Provided that the new rust fungus spreads to other members of the myrtle family, its spread and damage to strawberry guava could be a victory for conservation management in Hawaii, while its spread and damage to 'ohi'a would be seen as a catastrophe.

However, 'ōhi'a has been born among Hawaiian volcanoes and persisted over several millions of years as the keystone species in the Hawaiian rainforest. It has demonstrated enormous resilience (Mueller-Dombois et al., 2013). We may conclude that 'ôhi'a will not be eliminated from Hawaiian habitats as long as active volcanism is part of the Hawaiian geology. Even the perceived climate change will not eliminate 'ôhi'a; this tree species has endured many severe changes of climate in its historic past (Hotchkiss et al., 2000). But the effects of the two new threats (alien invaders and climate change) cannot be predicted presicely. That also implies that state transitions in ecosystems cannot be easily predicted. Nevertheless, they can be identified after they have occurred and thus provide knowledge for future expectancies.
Acknowledgements. Since this review paper is largely based on our 2013 book 'Ōhi'a Lehua Rainforest (now available via Amazon books Online), we feel obligated to acknowledge our two co-authors James D. Jacobi (PhD, 1990) and Jonathan P. Price ( $\mathrm{PhD}, 2002)$. In addition we wish to acknowledge five outstanding field researchers who passed away during this 5-decade long research project and to whom the above book is dedicated. They are Garrett A. Smathers (PhD 1972), Ranjit G. Cooray (MSc, 1974), Nengah Wirawan ( $\mathrm{PhD}, 1978)$, Nadaraja Balakrishnan ( $\mathrm{PhD}, 1985)$, and Lani Stemmermann (PhD, 1986). We also owe special thanks to Grant Gerrish (PhD, 1988), who among other significant contributions transferred the permanent plot work and accumulated data to Hans Juergen Boehmer (PhD, 1998). There are other outstanding contributors to the Hawaiian rainforest study, whose names are accredited in the above named book.

Edited by: R. F. Hüttl

\section{References}

Akashi, Y. and Mueller-Dombois, D.: A landscape perspective of the Hawaiian rainforest dieback, J. Veg. Sci., 6, 449-464, 1995.

Auclair, A. N. D.: Extreme climatic fluctuations as a cause of forest dieback in the Pacific rim, Water Air Soil Poll., 66, 207-229, 1993.

Boehmer, H. J.: Dynamik und Invasibilitaet des montanen Regenwaldes auf der Insel Hawaii (Dynamics and Invasibility of Hawaii's Montane Rainforest), Habilitation thesis, Department of Ecology and Ecosystem Management, Technical University of Munich, Germany, 232 pp., including six appendices, 2005.

Boehmer, H. J.: Vulnerability of tropical montane rain forest ecosystems due to climate change, in: Coping with Global Environmental Change, Disasters and Security - Threats, Challenges, Vulnerabilities and Risks, edited by: Brauch, H. G.; Spring, O. Ú., Mesjasz, C., Grin, J., Kameri-Mbote, P., Chourou, B., Dunay, P., and Birkmann, J., Hexagon Series on Human and Environmental Security and Peace, Berlin, Heidelberg, New York, Springer-Verlag, 5, 789-802,doi:10.1007/978-3-642-17776-7_6, 2011a.

Boehmer, H. J.: Störungsregime, Kohortendynamik und Invasibilität - zur Komplexität der Vegetationsdynamik im Regenwald Hawaiis. (Disturbance regimes, cohort dynamics, and invasibility - on the complexity of vegetation dynamics in Hawaii's rainforests), Laufener Spezialbeiträge 2011 "Landschaftsökologie Grundlagen, Methoden, Anwendungen”, 111-117, 2011b.

Boehmer, H. J. and Richter, M.: Regeneration of Plant Communities - An Attempt to Establish a Typology and Zonal System, Plant Research and Development, 45, 74-88, 1997.

Boehmer, H. J., Wagner, H. H., Gerrish, G. C., Jacobi, J. D., and Mueller-Dombois, D.: Rebuilding after Collapse: Evidence for long-term cohort dynamics in the Hawaiian rainforest, J. Veg. Sci., 24, 639-650, doi:10.1111/jvs.12000, 2013.

Burton, P. J. and Mueller-Dombois, D.: Response of Metrosideros polymorpha seedlings to experimental canopy opening, Ecology, 65, 779-791, 1984.

Carlquist, S.: Hawaii, a Natural History: Geology, Climate, Native Flora and Fauna above the shoreline, Second edition printed for the Pacific Tropical Botanic Garden by SB Printers, Inc., Honolulu, Hawasii, 468 pp., 1980. 
Doty, R. D.: Annual precipitation on the island of Hawaii between 1890 and 1977, Pac. Sci., 36, 421-425, 1982.

Drake, D. R.: Seed dispersal of Metrosideros polymorpha (Myrtaceae): a pioneer tree of Hawaiian lava flows, Am. J. Bot., 79, 1224-1228, 1992.

Drake, D. R. and Mueller-Dombois, D.: Population development of rain forest trees on a chronosequence of Hawaiian lava flows, Ecology, 74, 1012-1019, 1993.

Evenson, W. E.: Climate analysis of 'ōhi'a dieback area on the island of Hawaii, Pac. Sci., 37, 375-384, 1983.

Fosberg, F. R.: Derivation of the flora of the Hawiian Islands, 107119, in: Insects of Hawaii, Vol. I, edited by: Zimmerman, E. C., University of Hawaii Press, Honolulu, 1948.

Fox, R. L., de la Pena, R. S., Gavenda, R. T., Habte, M., Hue, N. V., Ikawa, H., Jones, R. C., Plucknet, D. L., Silva, J. A., and Soltanpour, P.: Amelioration, revegetation, and subsequent soil formation in denuded bauxitic materials, Allertonia, 6, 128-184, 1991.

Hodges, C. S. , K. T. Adee, J. D. Stein, H. B. Wood, and Doty, R. D.: Decline of 'ōhi'a (Metrosideros polymorpha) in Hawaii, General Technical Report PSW-86 Berkeley, CA, Pacific Southwest Forest and Range Experiment Station, Forest Service, US Department of Agriculture, 22 pp., 1986.

Hotchkiss, S., Vitousek, P. M., Chadwick, O. A., and Price, J. P.: Climate cycles, geomorphological change, and the interpretation of soil and ecosystem development, Ecosystems, 3, 522-533, 2000.

Jackson, T. A.: The role of pioneer lichens in the weathering of recent volcanic rocks on the island of Hawaii, Ph.D. Thesis, University of Missouri, Columbia, 212 pp., 1969.

Jacobi, J. D., Gerrish, G., and Mueller-Dombois, D.: 'Ōhi'a dieback in Hawaii: Vegetation changes in permanent plots, Pac. Sci., 37 , 327-337, 1983.

Jacobi, J. D., Gerrish, G., Mueller-Dombois, D., and Whiteaker, L.: Stand-level dieback and Metrosideros regeneration in the montane rainforest of Hawaii, GeoJournal, 17, 193-200, 1988.

Juvik, S. P. and Juvik, J. O.: Atlas of Hawaii, 3rd Edn., Honolulu, 1998.

Kitayama, K. and Mueller-Dombois, D.: Vegetation changes along gradients of long-term soil development in the Hawaiian montane rainforest zone, Vegetatio, 120, 1-20, 1995.

Kitayama, K., Mueller-Dombois, D., and Vitousek, P. M.: Primary succession of Hawaiian montane rain forest on a chronosequence of eight lava flows, J. Veg. Sci., 6, 211-222, 1995.

Loope, L. L. and Uchida, J.: The challenge of retarding erosion of island biodiversity through phytosanitary measures: an update on the case of Puccinia psidii in Hawaii, Pac. Sci., 66, 127-139, 2011.

Lyon, H. L.: Some observations on the forest problems of Hawaii, Hawaiian Planter's Record, 21, 289-300, 1919.

Manion, P. D.: Tree Disease Concepts, 2nd Edn., Prentice Hall, Englewood Cliffs, NJ, 402 pp., 1991.

Minden, V., Henneberg, K. J., Porembski, S., and Boehmer, H. J.: Invasion and management of alien Hedychium gardnerianum (kahili ginger, Zingiberaceae) alter plant species composition of a montane rainforest on the island of Hawaii, Plant Ecol., 206, 321-333, 2010a.
Minden, V., Jacobi, J. D., Porembski, S., and Boehmer, H. J.: Effects of invasive alien kahili ginger (Hedychium gardnerianum) on native plant species regeneration in a Hawaiian rainforest, Appl. Veg. Sci., 13, 5-14, 2010b.

Mueller-Dombois, D.: Perspectives for an etiology of stand-level dieback, Annu. Rev. Ecol. Syst., 17, 221-243, 1986.

Mueller-Dombois, D.: Natural dieback in forests: Groups of neighboring trees may die in response to natural phenomena, as well as to stress induced by human activity, BioScience, 37, 575-583, 1987.

Mueller-Dombois, D.: Canopy dieback and ecosystem processes in the Pacific area, in: Proceedings of the XIV International Botanical Congress, edited by: Greuter, W. and Zimmer, B., 445-465, Koeltz Scientific Books, Koenigstein, Germany, 1988a.

Mueller-Dombois, D.: Towards a unifying theory for stand-level dieback. GeoJournal, 17, 249-251, 1988b.

Mueller-Dombois, D.: A natural dieback theory, cohort senescence as an alternative to the decline disease theory, in: Forest Decline Concepts, edited by: Manion, P. D. and Lachance, D., 26-37, APS Press, The American Phytopathological Society, St. Paul, Minnesota, 249 pp., 1992a.

Mueller-Dombois, D.: Distributional dynamics in the Hawaiian vegetation, Pac. Sci., 46, 221-231, 1992b.

Mueller-Dombois, D.: Long-term rain forest succession and landscape change in Hawaii: The Maui Forest Trouble revisited, J. Veg. Sci., 17, 685-692, 2006.

Mueller-Dombois, D. and Fosberg, F. R.: Vegetation of the Tropical Pacific Islands. Springer-Verlag, New York, Berlin, Heidelberg, 733 pp., 1998.

Mueller-Dombois, D., Jacobi, J. D., Boehmer, H. J., and Price, J. P.: 'Ōhi'a Lehua Rainforest. Born among Hawaiian volcanoes, evolved in isolation, The story of a dynamic ecosystem with relevance to forests worldwide, Amazon Press, 274 pp., 2013.

Papp, R. P., Kliejunas, J. T., Smith Jr., R. S., and Scharpf, R. F.: Association of Plagithmysus bilineatus (Coleoptera: Cyrambicidae) and Phytophthora cinnamomi with the decline of 'ôhi'a-lehua forests on the island of Hawaii, Forest Sci., 25, 187-196, 1979.

Percy, D. M., A. M. Garver, W. L. Wagner, H. F. James, C. W. Cunningham, S. E. Miller, and Fleischer, R. C.: Progressive island colonization and ancient origin of Hawaiian Metrosideros (Myrtaceae), P. R. Soc. B, 275, 1479-1490, 2008.

Smathers, G. A. and Mueller-Dombois, D.: Hawaii, the Fires of Life: Rebirth in Volcano Land - Five Decades of Vegetation Development in the Devastation Area, Site of the 1959 Kilauea Iki Eruption, Hawaii Volcanoes National Park, Mutual Publishing Company, Honolulu, 142 pp., 2007.

Vitousek, P.: Nutrient Cycling and Limitation: Hawaii as a Model System. Princeton Environmental Institute Series. Princeton University Press, Oxford and Princeton, 223 pp., 2004.

Wagner, W. L., Herbst, D., and Sohmer, S. H.: Manual of the Flowering Plants of Hawaii. Revised edition, Bishop Museum special publication, 1-2, 1919 pp., 1999.

Wirthmann, A. and Hueser, K.: Vulkaninseln als Modelle tropischer Reliefgenese, Geographische Rundschau, 39, 22-31, 1987. 